\section{Comment on the impact of gene patents and licensing practices on access to genetic testing: Lessons from hereditary hemorrhagic telangiectasia}

\section{To the Editor:}

n the April 2010 supplement to this journal, a series of articles prepared by the Center for Public Genomics at Duke University analyzed how patenting and licensing affect access to clinical genetic testing for 10 disorders in the United States. In two of those cases, Canavan disease and cystic fibrosis (CF), the Duke researchers highlighted the influence of health care consumers and voluntary disease organizations in patent decision making and licensing. In their analysis, the Duke group found that involvement of patient advocacy organizations in patent planning can facilitate commercialization of clinical genetic tests to the benefit of all involved. On the other hand, efforts to neutralize the influence of prospective genetic testing consumers and their representative disease organizations only serve to alienate the groups most interested in the wide dissemination of the technology and reflect poorly on the universities and laboratories implementing the policy. Some of the Duke cases have recently also been used to argue for the value of enhanced stakeholder participation in biobanking. ${ }^{1}$ In this letter, we respond to those cases by noting their compatibility with our own recent research into the patent for genetic testing of Hereditary Hemorrhagic Telangiectasia (HHT). Through interviews with key participants in the decision-making process, we explored how and why the patent rights for the HHT test were voluntarily abandoned for the sake of effective commercialization.

\section{THE PUBLISHED CASES}

In the case of the patent for genetic testing of $\mathrm{CF}$, Chandrasekharan et al. ${ }^{2}$ reported that when considering patenting, gene discoverers at the University of Michigan and the Hospital for Sick Children in Toronto conferred with funding authorities and the $\mathrm{CF}$ Foundation. Among other contributions, the $\mathrm{CF}$ Foundation successfully joined with the gene discoverers to urge the use of nonexclusive licensing, noting that an exclusive license could impede needed future research on yet-to-be-discovered mutations and on the optimal technology for highsensitivity carrier detection. Once patents had been acquired, a broad, nonexclusive licensing approach was used. This approach assured wide clinical availability of the genetic test and allowed research to be pursued freely. In the only case of patent infringement discovered, the matter was resolved through a telephone call, not a cease-and-desist letter.

In the case of Canavan disease, by contrast, Colaianni et al. ${ }^{3}$ report that the Miami Children's Hospital filed for patents without informing patient groups or key stakeholders. This action took place despite the assiduous efforts of Rabbi Josef Ekstein and the Canavan Foundation to encourage large numbers of the Ashkenazi Jewish community to be screened for mutations associated with Canavan disease-efforts which took place while the first patent application was pending. Laboratories and hospitals providing testing services for the community received news of the first granted patent through the receipt of strongly worded cease-and-desist letters. Moreover, the proposed terms for licensees called for limitations on the number of tests allowed to be performed per year and relatively high royalty fees. In response, stakeholders and their supporters formed the Canavan Disease Screening Consortium, which attempted to negotiate less restrictive licensing terms. The negotiations yielded little fruit for the Consortium, leading them to sue Miami Children's Hospital, seeking through the courts what could not be obtained through negotiation and ultimately leading to a settlement. Media coverage of these events put the Children's Hospital in an extremely negative light. The authors concluded that failure to engage meaningfully with diseasespecific advocacy groups and other key stakeholders can lead to controversy, disruption of patient access to testing, and tarnishing of the reputations of scientists and their institutions.

\section{HHT BACKGROUND}

HHT is an autosomal dominant disorder affecting approximately 1 in 5000 people. ${ }^{4}$ The condition is characterized by underdevelopment and malformation of the network of blood vessels connecting the arteries to the veins, leading to a variety of clinical problems including frequent epistaxis, gastrointestinal bleeding, and brain, lung, and liver arteriovenous malformations, predisposing to the life-threatening complications of stroke, chronic hypoxemia, cerebral abscess, and cardiac failure. Both the severity and the age of onset of HHT are highly variable. Signs of HHT may not appear until adolescence or adulthood, making the diagnosis in young at-risk children and young adults difficult. Because of the variability in onset and expression of the disorder, a genetic test has clear clinical utility by determining which at-risk family members need to be worked up for possible clinical involvement.

\section{GENE DISCOVERY AND PATENTING}

Geneticist Douglas Marchuk at Duke University and biochemist Michelle Letarte at Toronto's Hospital for Sick Children share status as inventors on the patents for a molecular method for diagnosis of HHT (US 6,022,687 and US $6,562,957)$. Marchuk's involvement in this research began when Francis Collins offered him stored deoxyribonucleic acid (DNA) samples of two very large HHT families. Marchuk collaborated with Mary Porteous, who had collected samples from smaller HHT pedigrees in the United Kingdom. Linkage was established to chromosome 9q33-q34 by Marchuk's group ${ }^{5}$ and was also independently established by Shovlin et al. ${ }^{6}$ Marchuk realized that this region held a likely candidate gene, endoglin, which coded for a transforming growth factor- $\beta$ binding protein. Knowing that Michelle Letarte had done extensive work on endoglin, Marchuk contacted Letarte, who he says was "very forthcoming" with complementary DNA clones and other materials and information useful to establish that endoglin was the mutated gene causing HHT in the two large pedigrees. ${ }^{7}$ Other pedigrees collected in the interim did not link to endoglin, however. In those families, Marchuk subsequently discovered another causal gene, $A L K 1$, a receptor in the transforming growth factor- $\beta$ pathway. ${ }^{8}$ One additional gene, SMAD4 has been found to cause HHT and juvenile polyposis in rare families, ${ }^{9}$ but mutations in $E N G$ and $A L K 1$ account for HHT in approximately $85 \%$ of families. ${ }^{4}$

The discovery was shared between Duke University and the University of Toronto, and Duke took the role of assignee on the US patents. No international patents were pursued. Duke University made the initial filing in 1994 with the discovery of the endoglin gene and updated the filing as new research findings became available. The first patent was approved and issued by the US patent office in 2000. According to Duke's Director of 
Corporate Alliances \& Development, Alan Herosian, the University's goal was for the diagnostic test to be developed and made widely available to patients, in accordance with the University's view of Federal law guiding technology transfer of Federally funded research. "We were just kind of doing what we were obliged to do under Bayh-Dole" (personal interview, September 16, 2009). Duke was, therefore, willing to grant licenses to all qualified applicants nonexclusively and under liberal license terms.

\section{TEST DEVELOPMENT AND ATTEMPTS AT LICENSING}

Initially, even Duke's own clinical molecular diagnostics laboratory was not interested in adding HHT to their offered diagnostic services. At the time, the laboratory managers deemed the target market too small to justify setting up the assay. However, many HHT families had been clamoring for better tools to diagnose the disease. In the mid- to late $1990 \mathrm{~s}$, word spread through patient support group networks and conferences that a type of inheritance testing was possible-endoglin protein testing. Endothelial cells from veins were required for the analysis, and HHT families all over the world, anxious to know whether their newborn children were affected, began express-mailing cold-packed umbilical cord samples to Letarte's research laboratory in Toronto. Letarte performed the desired analyses; however, all the findings had to be reported as "research results." Although Letarte performed protein testing on a research basis, Marchuk was working with DNA and performed genetic testing for families who desired it. However, the results likewise were reported as research results. Although the families had obtained the information they sought, their physicians were effectively gagged by law when asked for advice on the basis of a research report. Through the late 1990s into the early 2000s, these two laboratories were the sole outlets for HHT testing in North America, and it was all done on a research basis.

With molecular testing technically feasible in the early 2000s, Yale University radiologist and HHT specialist Robert White meanwhile began working to establish HHT Centers of Excellence to offer specialized treatment and diagnostic services to families with HHT. The University of Pennsylvania and the University of Utah were well positioned to launch Centers of Excellence and molecular testing. However, when White approached the University of Pennsylvania about offering HHT genetic testing services, the Director of the Molecular Diagnostics Laboratory, Arupa Ganguly, demurred. She had recently received a cease-and-desist letter from Myriad Genetics over testing for the BRCA1 gene. It was not clear whether Duke would likewise protect the HHT test patent. Therefore, Ganguly would not consider doing HHT testing until a licensing agreement had been made (personal interview, November 20, 2009). Nevertheless, despite the nonexclusive, nonrestrictive terms offered by Duke, license negotiations stalled. As Herosian recalled, neither Utah nor Penn would accept terms for indemnification of Duke University that he considered to be standard language.

Although these negotiations lagged, Letarte and her colleagues in Toronto helped to set up a commercial laboratory, HHT Solutions, which began to offer clinical testing in Canada in 2003. Frustrated by the stalled license negotiations for the prospective US testing laboratories, in December 2002, the HHT Foundation (now headed by Marianne Clancy, who had previously been serving on the board), assembled a Task Force composed of medical and genetic experts to look into the issue. Clancy felt that it was "not in the best interest of HHT families- who gave their blood, by the way [for research], and were sending their blood and their children's umbilical cords to find this gene in the first place"- not to be able to access genetic testing in a laboratory in the United States (personal interview, May 20, 2009). The Task Force consulted with University of Maryland patent expert Lawrence Sung for information. Then at a 2003 HHT international conference in Bonaire, Marianne Clancy presented a report of the Task Force, expressing frustration over the inability of US-based laboratories to put HHT testing online and noting that the Foundation had consulted an attorney. She argued that the patent needed to be eliminated to move forward with establishment of CLIA-approved US laboratories.

Named inventor Marchuk was open to relinquishing the patent rights (personal interview, August 5, 2009). Focused on his research, he was unaware of the specific negotiations over licensing and uncertain whether the patent was ultimately harmful to patients. However, for him, the benefit of the doubt went to the HHT Foundation. In response to Clancy's request, he wrote a letter to Duke's Alan Herosian dated May 23, 2003, recommending that the patent rights be abandoned. After a number of earnest private discussions with Clancy, coinventor Letarte also ultimately agreed to abandon the rights to the patent.

From Herosian's perspective in Duke's Office of Licensing and Ventures, the patent had cost money to file and cost more money to maintain but was producing relatively little revenue. Rather than creating incentive to commercialize the test, the patent seemed to have become an impediment to commercialization. The answer to the negotiation stalemate over indemnification was to put the patent in the public domain and forego licensing.

According to Clancy, within 60 days of the Bonaire meeting, she had letters from Duke and Toronto relinquishing the patents. The HHT Foundation provided \$10,000 start-up grants to three laboratories to initiate HHT genetic testing: ARUP Laboratories in Utah, the University of Pennsylvania molecular diagnostic laboratory, and HHT Solutions in Toronto. Within 30 days of receiving the grants, these laboratories were offering HHT molecular diagnostic testing. In addition to these laboratories, Ambry Genetics (in California) and the Hospital for Sick Children in Toronto currently also offer HHT genetic testing.

\section{CONCLUSIONS}

It is unclear whether a resolution to the license dispute would have eventually been found. However, in 2002 stalled license negotiations were thwarting the establishment in the US of HHT genetic testing laboratories approved under the Clinical Laboratory Improvement Amendments, hindering access of US patients to non-research-based clinical testing. Because lucrative profits were not at stake (given the relatively small target market), the parties to the negotiations may have felt that the potential liability risk outweighed the financial benefits of licensing. Whatever the case, the lack of revenue coming from the patent clearly contributed to a relatively controversy-free decision to relinquish patent rights.

Nevertheless, without the intervention of the HHT Foundation, the stalemate over US commercialization might have continued indefinitely. In this case, although the HHT Foundation was not consulted during the patenting process, the intended licensing strategy was generally consistent with what the Foundation would have desired. Absent stalled licensing negotiations, the HHT Foundation would likely have remained on the sidelines of the patent. Notably, however, action came relatively swiftly when Clancy made the Foundation's objections known. The case speaks to the relationship building that took place 
between the HHT Foundation and HHT researchers: consensus was achieved in personal telephone calls between Clancy, Marchuk, and Letarte and then between the inventors and their respective intellectual property officers, without the intervention of lawyers or professional arbitrators. In this manner, the HHT case bolsters the conclusions of Colaianni et al. ${ }^{3}$ that inclusion of patient representatives in patent decision making fosters commercialization of diagnostic tests. The case underscores the importance of fostering healthy relationships and consensusbuilding between patent holders and members of the public their inventions ultimately serve-a principle thoroughly breached by the Miami Children's Hospital in the Canavan case. The importance of involvement of patient advocacy groups in gene patenting has also been highlighted in the case of psuedoxanthoma elasticum where the patient advocacy group, PXE International, actively participated in the research to discover the causative gene, funded the necessary research, and is named on the gene patent as inventor. ${ }^{10,11}$

Additionally, the HHT case echoes some of the conclusions offered in a recent report to the Secretary's Advisory Committee on Genetics, Health, and Society (where the articles published in the April supplement can be found as Appended case studies). ${ }^{12}$ The report concluded that most genes are discovered in the context of academic science, where scientific exploration, publishing, and recognition are the primary motivators for researchers. Hence, in the area of gene discovery, patenting is not necessary as a spur to innovation. Similarly, the report noted that once a gene has been identified, the development costs for a genetic test are relatively low. Hence, patenting is not generally necessary for commercialization of useful genetic tests. The HHT patent case supports these conclusions fully.

\section{ACKNOWLEDGMENTS}

This research was supported by grant number 1P50HG004487-01 from the National Human Genome Research Institute (NHGRI).

Donna A. Messner, PhD

Chemical Heritage Foundation Division of Medical Genetics Penn Center for the Integration of Genetic Health Care Technologies Hospital of the University of Pennsylvania Philadelphia, Pennsylvania

Reed E. Pyeritz, MD, PhD Barbara A. Bernhardt, MS, CGC Division of Medical Genetics Penn Center for the Integration of Genetic Health Care Technologies Hospital of the University of Pennsylvania Philadelphia, Pennsylvania Disclosure: Dr. Pyeritz is a member of the HHT Foundations Global Research and Medical Advisory Board. The other authors have no conflict of interest to disclose.

\section{REFERENCES}

1. Heaney C, Carbone J, Gold R, et al. The perils of taking property too far. Stanf J Law Sci Policy 2009;1:46-64.

2. Chandrasekharan S, Heaney C, James $\mathrm{T}$, et al. Impact of gene patents and licensing practices on access to genetic testing for cystic fibrosis. Genet Med 2010;12:S194-S211.

3. Colaianni A, Chandrasekharan S, Cook-Deegan R. Impact of gene patents and licensing practices on access to genetic testing and carrier screening for Tay-Sachs and Canavan disease. Genet Med 2010;12:S5-S14.

4. Faughnan ME, Palda VA, Garcia-Tsao G, et al. International guidelines for the diagnosis and management of hereditary hemorrhagic telangiectasia [published online ahead of print June 29, 2009]. J Med Genet doi: 10.1136/ jmg.2009.069013.

5. McDonald MT, Papenberg KA, Ghosh S, et al. A disease locus for hereditary haemorrhagic telangiectasia maps to chromosome 9q33-34. Nat Genet 1994;6:197-204

6. Shovlin CL, Hughes JM, Tuddenham EG, et al. A gene for hereditary haemorrhagic telangiectasia maps to chromosome 9q3. Nat Genet 1994;6: 205-209.

7. McAllister KA, Grogg KM, Johnson DW, et al. Endoglin, a TGF-beta binding protein of endothelial cells, is the gene for hereditary haemorrhagic telangiectasia type 1. Nat Genet 1994;8:345-351.

8. Johnson DW, Berg JN, Baldwin MA, et al. Mutations in the activin receptorlike kinase 1 gene in hereditary haemorrhagic telangiectasia type 2. Nat Genet 1996;13:189-195.

9. Gallione CJ, Richards JA, Letteboer TG, et al. SMAD4 mutations found in unselected HHT patients. J Med Genet 2006;43:793-797.

10. Ledbetter DH. Gene patenting and licensing: the role of academic researchers and advocacy groups. Genet Med 2008;10:314-319.

11. Terry SF, Terry PF, Rauen KA, et al. Advocacy groups as research organizations: the PXE international example. Nat Rev Genet 2007;8:157-164.

12. Secretary's Advisory Committee on Genetics, Health, and Society. Revised draft report on gene patents and licensing practices and their impact on patient access to genetic tests. US Department of Health and Human Services, April 2010. Available at: http://oba.od.nih.gov/oba/sacghs/reports/ SACGHS_patents_report_2010.pdf. Accessed September 9, 2010.

\section{Response to ACMG Practice Guidelines and ACMG Standards and Guidelines, Genetics in Medicine, July 2010, volume 12, number 7, pages 446-463 and 464-470}

\section{To the Editor:}

enjoyed reading the two documents by the standards committee in collaboration with Dr. Kishnani and her associates. ${ }^{1}$ This is a well laid out document and provides excellent guidelines for the management of children with type III glycogen storage disorder (GSD III).

One item worth commenting on is the mention of cardiomyopathy that occurs in some patients with GSD III. As mentioned by the authors, this is a complication that may occur over time despite recommended therapy with good compliance.

I would like to relay my experience with a patient who highlights this particular phenomenon. The clinical events with this patient potentially provide some insight into this problem. This patient is a white male with GSD III who was managed from 11 months of age with a high-protein/low-carbohydrate diet through frequent feeds during the day and a continuous nocturnal drip with high-protein liquid formulas. (Although current standards involve the use of cornstarch and high-protein supplementation - not necessarily by continuous infusion-this has not always been the case. Single-mode therapy was prescribed for this patient in the 1980s). As he was followed up, frequent assessments of liver function consistently showed mildly elevated levels of these parameters. At approximately 10 years of age, the patient requested a switch to cornstarch to avoid the inconvenience of the nighttime drip. This change was made at his/his family's request. Notably, a dramatic rise in CK levels with no change in liver function studies were noted after this change, with a rise in the MB fraction. After just a couple months of cornstarch treatment, his therapy was returned to 
Table 1 Enzyme levels with changes in therapy

\begin{tabular}{lcl}
\hline & On high-protein regimen & On cornstarch regimen \\
\hline ALT & $150-600$ (mean, 300) & No change \\
LDH & $350-700$ (mean, 500) & No change \\
Gamma GT & $150-400($ mean, 80) & No change \\
CK & $480-540($ mean, 500) & 1154 to peak of 3754 \\
CK \% MB & $2.5-3.5 \%$ & Peak 7\%
\end{tabular}

ALT, alanine amintransferase; LDH, lactate dehydrogenase; GGT, gamma glutamyl transpeptidase; $\mathrm{CK}$, creatine kinase; $\mathrm{CK} \% \mathrm{MB}$, muscle-brain fraction of $\mathrm{CK}$.

high-protein feeds with the discontinuation of the cornstarch. Commensurably, his CK levels returned to baseline. Also, the $\mathrm{MB}$ fraction returned to a nonalarming state. Cardiac imaging studies were not performed before or after this occurrence (Table 1).
I send this letter to share this experience with others who care for these patients. The changes that were observed were dramatic. For this patient, it seems that some difference in the cornstarch regimen, when compared with the high-protein therapy was responsible for accentuating a cardiomyopathy. I recognize that from the perspective of a single case report, no firm conclusions can be drawn nor can any specific recommendations be made. More cases and systematic study would be needed to determine whether this is phenomenon, which might be seen in additional patients.

\section{G. Bradley Schaefer, MD, FAAP, FACMG}

University of Arkansas for Medical Sciences Arkansas Children's Hospital Little Rock, Arkansas

Disclosure: The author declares no conflict of interest.

\section{REFERENCE}

1. Kishnani PS, Austin SL, Arn P, et al; ACMG. Glycogen storage disease type III diagnosis and management guidelines. Genet Med 2010;12:446-463. 